\title{
Postural Disorders of the Lower Extremities in Children of the Younger School Age
}

\author{
Veljko Vukicevic ${ }^{1}$, Nikola Lukic ${ }^{1}$, Jovanka Mimic ${ }^{1}$ \\ 'University of Novi Sad, Faculty of Sport and Physical Education, Novi Sad, Serbia
}

\begin{abstract}
The aim of the study is to evaluate and determine the differences in the status of lower limbs of primary school pupils in primary school. On the sample of 68 respondents, 34 boys and 34 girls, who attended the first grade of the primary school "Ivo Lola Ribar" from Novi Sad, an assessment of the postural status by the method of "Napoleon Wolansky" was carried out with an accent on " $\mathrm{X}$ " and "O" the shape of the leg and the holding of the vault of the soles. For the statistical data processing, the non - parametric $\mathrm{Hi}$ - square test method was used. The results showed that statistically significant differences were not found, indicating a similar state of the observed segments of the postural status of this sample $(p>0.05)$. In the leg estimation variables, it can be concluded that there are no statistically significant differences between boys and girls in the segments of the " $X$ " leg ( $p=0.323)$, as well as the "O" leg $(p=0.555)$. No statistically significant differences were observed between the subjects of the different sex $(p=0.614)$ nor at the foot of the foot. A slightly higher representation of the good holding of this segment was observed in the sub-girlfriends. The results show that flat feet were represented with $7.48 \%$ of the total sample. Based on the results it can be concluded that it is generally necessary to apply preventive exercises and activities in the teaching of physical education, but also to work towards the early diagnosis of these deformities.
\end{abstract}

Key words: Boys, Girls, Foot, Foot Shape, Differences

\section{Uvod}

Savremeni i urbani uslovi kakvo nam nameće okruženje često nepovoljno utiču na posturalni status i naročito na deformitete stopala. Hipokinezija i nedostatak kretanja ostavlja posljedice u vidu nedovoljne aktivacije mišića cijeloga tijela a posebno nogu. Deformiteti koji nastaju su donekle genetski determinisani, a na njih utiču različiti egzogeni faktori, pa se promjene na stopalu i koljenu javljaju u velikom broju slučajeva.

Stopalo je jedan od najkomplikovanijih anatomskih segmenata organizma, čiji koštani dio se sastoji od 26 kostiju i 32 zgloba koji obezbjeđuju dvije važne funkcije stopala: stajanje (statička funkcija) i hodanje (dinamička funkcija) (Jovičić, 2007). To nas navodi na stav da ono mora biti pravilno konstruisano da bi izdržalo sile tokom stajanja ali i da se prilagodi podlozi, amortizuje i djeluje tokom hodanja. Struktura stopala je takva da se funkcijama tri svoda održava stabilnost i neophodna elastičnost. Neadekvatno reagovanje i kasna de- tekcija ovoga poremećaja je takođe jedan od razloga što mnoga djeca imaju deformitet stopala. Mnoga istraživanja ukazuju na činjenicu da je ravno stopalo najčešći poremećaj donjih ekstremiteta i da je njegova zastupljenost kod školske djece u velikom procentu (R. Krsmanović, Mijanović, S. Krsmanović, i B. Krsmanović, 1995; Jovović, 1999; Videmšek, Klopčič, i Karpljuk, 2006; Mihajlović, Tončev, i Hmjelovjec, 2008; Trajković i Nikolić, 2008; Bogdanović i Marković, 2010; Protić Gava i Krneta, 2010). Takva pojava karakteriše se popuštanjem i slabljenjem svodova stopala što dovodi do gubljenja njegovih fizioloških i funkcionalnih svojstava. (Jovović, 1999; Jovović i Čanjak, 2012). Ona djeca koja ranije prohodaju, ona koja su fizički nedovoljno aktivna i gojazna imaju povećan rizik od nastanka deformiteta stopala (Pfeiffer, Koty, Ledl, Hauser, i Sluga, 2006). Interesantan je podatak da je ravno stopalo posturalni poremećaj koji se vrlo rijetko sreće kod seoske djece (Živković i Karaleić, 1996)

\section{Correspondence:}

\section{Montenegro}

Sport

\section{Vukicevic}

University of Novi Sad, Faculty of Sport and Physical Education, Novi Sad, Serbia

E-mail: vukicevicveljko9@gmail.com 
Narušavanje statike nogu i djelovanja na koljeno dovodi do promjene oblika nogu, odnosno pojave narušavanja unutrašnjih i spoljašnjih struktura. Takvi poremećaji najčešće dovode do deformiteta koljena (Radisavljević, 2001; Jovović, 2008). Deformacija nogu lokalizovana u predjelu zgloba koljena sa lučnim iskrivljenjem natkolenice i potkolenice okrenutim ka unutra označava se kao „X“ noge (Gene Valgum). Istraživanja ukazuju da je ovaj poremećaj čest uzrok nastanaka spuštenog svoda stopala usled disbalansa nadkoljenice i potkoljenice. Poremećaj mišićne i ligamentne strukture u oba deformiteta nogu („X“ $\mathrm{i}$ „O “ noge) je često povezan sa rahitisom stoga samo oboljenje nije jednostavno i sa sobom nosi i dodatne komplikacije. „O“ noge (Genu Varum) je deformitet kod koga natkoljenice i potkoljenice sa vrhom u zglobu koljena grade lučno iskrivljenje sa konveksitetom ka spolja. Najčešće se javljaju kod djece koja su forsirana da što prije počnu da hodaju i kod onih koja imaju statički poremećaj van koljena, a uzrok može biti i rahitis (Jovović, 2008).

Različitim metodama i analizama utvrđeno je da se svaka promjena i disbalans na tijelu, a pogotovo na donjim ekstremitetima i stopalu može odraziti na poremećaje posturalnog i funkcionalnog stanja cjelokupnog tijela.

Do prije trideset i više godina preovladavala su mišljenja i stavovi da učenike sa tjelesnim deformitetima ne bi trebalo uključivati u nastavu fizičkog vaspitanja. U poslednje vrijeme takva mišljenja su uglavnom promijenjena, tako da se u većini prihvata stav da je ovoj djeci itekako potrebna fizička aktivnost. Na ovakva opredeljenja sigurno su uticala mnoga naučna istraživanja koja pokazuju da fizičke aktivnosti koje djeluju na organizam za vrijeme redovnih časova fizičkog vaspitanja ne mogu da ugroze i pogoršaju njihovo stanje. Pažljivo odabrani i pravilno primijenjeni kompleks vježbi na ovakve učenike može uspješno uticati u pravcu popravljanja držanja tijela, a time i na smanjenje funkcionalnih deformiteta kao i stanja svoda stopala.

Cilj istraživanja je procjena posturalnog statusa donjih ekstremiteta učenika prvih razreda osnovne škole „Ivo Lola Ribar“ iz Novog Sada, odnosno utvrđivanje posturalnog statusa stopala i zgloba koljena kod učenika mlađeg školskog uzrasta, a takođe utvrđivanje razlike kod ispitanika muškog i ženskog pola u statusu donjih ekstremiteta ( „O“ noge).

\section{Metod}

Uzorak ispitanika čini 68 učenika prvih razreda Osnove škole „Ivo Lola Ribar“ iz Novog Sada, podijeljan na dva subuzorka: prvi subuzorak su činili 34 ispitanika muškog pola a drugi subuzorak 34 ispitanika ženskog pola. U istraživanje su uključeni samo oni učenici prvog razreda čiji su roditelji dali pismenu saglasnost. Na navedenom uzorku ispitanika izvršena je procjena posturalnog statusa po metodi Napoleona Wolanskog (Protić-Gava i Šćepanović, 2012) sa akcentom na oblik nogu i držanje svoda stopala. Po metodi Napoleona Wolanskog, postoje tri ocjene: 0,1 i 2 . Ocjena 0 se daje kada se svi indikatori nalaze u normalnim odnosima - normalan status. Ocjena 1 predstavlja određeno odstupanje od normalnog statusa držanja tijela i uspješno se može sanirati kroz nastavu fizičkog vaspitanja (ovo odstupanje bi se moglo podvesti pod funkcionalni stadijum deformiteta, kada dolazi do popuštanja aktivnog dijela lokomotornog aparata). Ocjenu 2 karakterišu znatna odstupanja od normalnog statusa držanja tijela. Procjena posturalnog statusa je bila obavljeno u osnovnoj školi „Ivo Lola Ribar“ u učiteljskoj sobi od strane studenata Fakulteta sporta i fizičkog vaspitanja, Procjena i mjerenje ispitanika izvršena je 2017. godine u Osnovnoj školi „Ivo Lola Ribar“ u Novom Sadu. Prilikom pregleda djeca su bila bosa i u donjem vešu. Inspekcija je izvršena sa udaljenosti od oko 2 metra i tom prilikom su posmtrani oblici nogu i stopala sa zadnje i bočne strane. Ocjene posturalnog statusa koljena i stopala upisani su u mjernu listu.

Za statističku obradu podataka bila je korišćena neparametrijska metoda Hi - kvadrat test, tačnije unakrsno tabeliranje, gdje su se dobile frekvencije za svaku kombinaciju parova kategorija varijabli i to za sve ispitivane varijable posturalnog statusa, kao i vrijednost Hi - kvadrat testa kojim je bilo utvrđeno da li postoji statistički značajna razlika između grupa ispitanika u držanju pojedinih segmenata posturalnog statusa tijela i donešeni konkretni zaključci na nivou statističke značajnosti od $\mathrm{p} \leq 0,05$.

\section{Rezultati}

Rezultati dobijeni Hi - kvadrat testom ukazuju na to da ne postoji statistički značajna razlika između dva subuzorka ispitanika, dječaka i djevojčica u segmentu „X“ noge ( $\mathrm{p}=0.323)$. Ispitanici različitog pola su sličnog stanja posturalnog statusa posmatranih segmenata, koji se može ocijeniti kao genaralno dobar. Brojčano posmatrano, više je dječaka imalo neki poremećaj zgloba koljena u odnosu na djevojčice istog uzrasta.

Tabela 1. Brojčana i procentualna zastupljenost „X" nogu i značajnost razlika po polu.

\begin{tabular}{|c|c|c|c|c|}
\hline & \multirow{2}{*}{ “X" oblik nogu } & \multicolumn{2}{|c|}{ Pol } & \multirow{2}{*}{ Ukupno } \\
\hline & & Dječaci & Djevojčice & \\
\hline \multirow{3}{*}{0} & Broj & 27 & 30 & 57 \\
\hline & $\%$ u odnosu na "X" oblik nogu & $47.4 \%$ & $52.6 \%$ & $100.0 \%$ \\
\hline & $\%$ u odnosu na pol & $79.4 \%$ & $88.2 \%$ & $83.8 \%$ \\
\hline \multirow{3}{*}{1} & Broj & 7 & 4 & 11 \\
\hline & $\%$ u odnosu na " $X$ " oblik nogu & $63.6 \%$ & $36.4 \%$ & $100.0 \%$ \\
\hline & $\%$ u odnosu na pol & $20.6 \%$ & $11.8 \%$ & $16.0 \%$ \\
\hline \multirow{3}{*}{ Ukupno } & Broj & 34 & 34 & 68 \\
\hline & $\%$ u odnosu na " $X$ " oblik nogu & $50.0 \%$ & $50.0 \%$ & $100.0 \%$ \\
\hline & $\%$ u odnosu na pol & $100.0 \%$ & $100.0 \%$ & $100.0 \%$ \\
\hline
\end{tabular}

Legenda: $x^{2}$-vrijednost Hi kvadrat testa; $p$-nivo statistčke značajnosti Hi-kvadrat testa; **-non-significant; **-significant difference between groups 
Slični podaci dobijeni su analizom brojčane i procentualne zastupljenosti varijable „O“ noge kod ispitanika različitog pola. Takođe nisu uočene statistički značajne razlike između subuzoraka isptanika u pogledu ove varijable za procenu stanja zgloba koljena zbog evidentiranih sličnih ocjena $(\mathrm{p}=0.555)$. Generalno se može istaći da ovaj deformitet nije zastupljen ili je pak jako slabo zastupljen na ispitanom uzorku djece.

Tabela 2. Brojčana i procentualna zastupljenost "O“ nogu i značajnost razlika po polu

\begin{tabular}{|c|c|c|c|c|}
\hline & \multirow{2}{*}{ “O” oblik nogu } & \multicolumn{2}{|c|}{ Pol } & \multirow{2}{*}{ Ukupno } \\
\hline & & Dječaci & Djevojčice & \\
\hline \multirow{3}{*}{0} & Broj & 33 & 30 & 65 \\
\hline & \% u odnosu na "O" oblik nogu & $50.8 \%$ & $49.2 \%$ & $100.0 \%$ \\
\hline & $\%$ u odnosu na pol & $97.1 \%$ & $94.1 \%$ & $95.6 \%$ \\
\hline \multirow{3}{*}{1} & Broj & 1 & 2 & 3 \\
\hline & \% u odnosu na "O" oblik nogu & $33.3 \%$ & $66.7 \%$ & $100.0 \%$ \\
\hline & $\%$ u odnosu na pol & $2.9 \%$ & $5.9 \%$ & $4.4 \%$ \\
\hline \multirow{3}{*}{ Ukupno } & Broj & 34 & 34 & 68 \\
\hline & \% u odnosu na "O" oblik nogu & $50.0 \%$ & $5 ., 0 \%$ & $100.0 \%$ \\
\hline & $\%$ u odnosu na pol & $100.0 \%$ & $100.0 \%$ & $100.0 \%$ \\
\hline
\end{tabular}

Legenda: $x^{2}$-vrijednost Hi kvadrat testa; $p$-nivo statistčke značajnosti Hi-kvadrat testa; **-non-significant;

**-significant difference between groups

$\mathrm{Na}$ osnovu rezultata tabele 3, može se konstatovati da nisu uočene statistički značajne razlike između ispitanika različitog pola $(\mathrm{p}=0.614)$. Ovakvim rezultatima doprinijela su slična stanja svoda stopala dječaka i djevojčica. Potrebno je istaći da je normalnog držanjem bio ukupno 21 ispitanik, sa ocjenom 1 , oštećenje u vidu slabljenja ligamenata i mišića koji drže uzdužni svod stopala 36 ispitanika i sa strukturalnim poremećajem u vidu spuštenog stopala "Pes Planovalgus" je bilo 11 ispitanika. Nešto malo veća zastupljenost dobrog držanja ovog segmenta je uočena u subuzorku djevojčica. Sa ocjenom 1 (što se može okarakterisati kao Pes Planus položaj stopala sa slabom - insuficijentom muskulaturom) je bilo 17 dječaka, i 19 djevojčica. Sagledano kroz subuzorke, skoro polovina ispitanika, bez obzira na polnu pripadnost ima početni stepen spuštenosti svoda stopala. Sa ocjenom 2, što bi moglo da se okarakteriše kao totalno spušten svod stopala, bilo je 7 dječaka i 4 djevojčice. Kada bi sumirali rezultate, rekli bismo da je 11 ispitanika, imalo ravna stopala što predstavlja $7.48 \%$ ukupnog uzorka.

Tabela 3. Brojčana i procentualna zastupljenost spuštenog svoda stopala i značajnost razlika po polu

\begin{tabular}{|c|c|c|c|c|}
\hline & \multirow{2}{*}{ Svod stopala } & \multicolumn{2}{|c|}{ Pol } & \multirow{2}{*}{ Ukupno } \\
\hline & & Dječaci & Djevojčice & \\
\hline \multirow{3}{*}{0} & Broj & 10 & 11 & 21 \\
\hline & $\%$ u odnosu na svod stopala & $47.6 \%$ & $52.4 \%$ & $100.0 \%$ \\
\hline & \% u odnosu na pol & $29.4 \%$ & $32.4 \%$ & $30.9 \%$ \\
\hline \multirow{3}{*}{1} & Broj & 17 & 19 & 36 \\
\hline & $\%$ u odnosu na svod stopala & $47.2 \%$ & $52.8 \%$ & $100.0 \%$ \\
\hline & $\%$ u odnosu na pol & $50.0 \%$ & $55.9 \%$ & $52.9 \%$ \\
\hline \multirow{4}{*}{ Ukupno } & Broj & 7 & 4 & 11 \\
\hline & $\%$ u odnosu na svod stopala & $50.0 \%$ & $50.0 \%$ & $100.0 \%$ \\
\hline & \% u odnosu na pol & $100.0 \%$ & $100.0 \%$ & $100.0 \%$ \\
\hline & & $x^{2}=0$ & $=0.614^{* *}$ & \\
\hline
\end{tabular}

Legenda: $x^{2}$-vrijednost Hi kvadrat testa; $p$-nivo statistčke značajnosti Hi-kvadrat testa; ${ }^{* *}$-non-significant;

**-significant difference between groups

\section{Diskusija}

Između dječaka i djevojčica obuhvaćenih ovom studijom statistički značajne razlike nisu pronađene, što ukazuje na slično stanje posmatranih segmenata posturalnog statusa ovog uzorka ( $\mathrm{p}>0.05$ ). Kod oba subuzorka procenat funkcionalnih deformiteta je u blagom porastu u sve tri ispitivane varijable. $\mathrm{Na}$ osnovu dobijenih rezultata može se konstatovati da je broj deformiteta stopala sličan kod oba pola ispitanika. Ovi rezultati istraživanja su u skladu sa rezultatima (Mihajlović, Šolaja, i Petrović, 2010). Takođe dobijeni rezultati se poklapaju sa rezultatima statusa nogu kod djece predškolskog uzrasta sa teritorije Novog Sad (Tot, 2001; Sabo, 2003). Manji je procenat u odnosu na rezultate (Živković, 2009; Karaleić, 1996; Mihajlović i Tončev, 2008). Na osnovu rezultata istraživanja, zaključuje se da djeca u tom uzrastu imaju krajnje nezadovoljavajući inicijalni status stopala koji se mansifestuje kroz izuzetno sla- bu muskulaturu mišića nogu, pogotovo mišića odgovornih za uzdužni svod stopala. Insuficijentna muskulatura, nedovoljna fizička aktivnost, nedostatak kretanja, još manja zastupljenost usmjerenih fizičkih aktivnosti doprinose pojavi ravnih stopala kod djece mlađeg školskog uzrasta. Nemogućnost da se djeca slobodno kreću, bosa po travnatim, pjeskovitim ili šljunkovitim podlogama zbog urbanizovane sredine, asfalta, a takođe i loši uslovi života, doprinijela su pojavi velikog procenta deformiteta u obliku ravnih stopala ( $16.2 \%$ ocjena 2$)$ kod ovog uzorka djece iz Novog Sada i velikog procenta funkcionalnog stadijuma deformiteta (52.9\% ocjena 1$)$. Pojava deformiteta svoda stopala je posljedica najvjerovatnije slabosti tonusa mišića, kratkih tabanskih mišića i mišića potkoljenice. Rezultati istraživanja takođe potvrđuju jedan dio ranijih istraživanja vezanih za stanje zgloba koljena (Radisavljević, Ulić, i Arunović 1997), koji su takođe utvrdili da razlike u pogledu oblika zglo- 
ba koljena ne postoje, ali da postoje ispitanici sa narušenim segmentom posturalnog statusa u vidu „X“ ili „O “ nogu ispitanika oba pola. Na osnovu dobijenih rezultata istraživanja, može se zaključiti sljedeće, ne postoje statistički značajne razlike kod ispitanika muškog i ženskog pola u varijablama „X“ noge, „O" noge i svod stopala, takođe, veliki broj ispitanika oba pola ima blaži, funkcionalni stadijum posturalnog poremećaja svoda stopala (52.9\% imalo je ocenu 1), dok u pogledu varijabli za procjenu oblika nogu, kod ispitanika oba pola dobijeni su slični rezultati, koji se mogu okarakterisati kao dobri. Generalno se može zaključiti da je stanje zgloba koljena u ispitivanoj populaciji zadovoljavajuće, dok je stanje svoda stopala zabrinjavajuće te se detekciji, prevenciji i korekciji mora posvetiti veća pažnja.

Značaj ovog istraživanja je taj što je ukazao na potrebu uključivanja u korektivni rad djece kod koje su detektovani neki od posturalnih poremećaja. Ukazao je i na potrebu vježbanja radi poboljšanja opšteg zdravstvenog stanja, bolje fizičke sposobnosti, bolje koordinacije i poboljšanja ostalih antropomotoričkih sposobnosti. Somatoskopska metoda Napoleona Wolanskog pokazuje svoje nedostatke koji se ogledaju u nedostatku objektivnosti ispitivača. To je vjerovatno i uzrok malog broja istraživanja koja primjenjuju ovu metodu za procjenu posturalnog statusa, jer u današnje vrijeme informacionih tehnologija, ova metoda je zamijenjena drugim laboratorijskim, ali one nijesu primjenljive na veće uzorke ispitanika.

Rezultati ukazuju na to da ovaj problem treba detaljnije istražiti i pratiti, obzirom da se radi o djeci predškolskog uzrasta i o tzv. funkcionalnim stadijumima deformiteta, koji se uspješno mogu otkloniti odgovarajućim korektivnim radom $\mathrm{u}$ vrtićima ili nekim vanškolskim ustanovama. Postoji opravdana potreba za utvrđivanjem stanja svoda stopala i oblika nogu kod dece svih uzrasta, što se predlaže za neka druga istraživanja. Takođe je potrebno izvršiti i odgovarajuća longitudinalna istraživanja na istom uzorku ispitanika, kako bi se dobili relevantniji podaci koji se mogu dovesti i u vezu sa promjena usled rasta i razvoja djece.

\section{Acknowledgements}

There are no acknowledgements.

\section{Conflict of Interest}

The authors declare that there are no conflicts of interest.

Received: 1 October 2018 | Accepted: 1 November 2018 | Published: 25 January 2019

\section{References}

Bala, G., Popović, B., i Đorđić, V. (2006). Fizička aktivnost devojčica i dečaka predškolskog uzrasta (monografija). Novi Sad: Fakultet fizičke kulture.

Bogdanović, Z. (2008), Deformiteti kičmenog stuba u sagitalnoj ravni. Novi Pa- zar: Državni Univerzitet u Novom Pazaru, Department za biohemijske i medicinske nauke.

Bogdanović, Z., i Marković, Ž. (2010). Prisustvo deformiteta stopala u zavisnosti od pripadnosti polu. Glasnik Antropološkog društva Srebije, 45(1), 397-402.

Jovičić, M. (2007). Fleksibilno ravno stopalo kod dece: problem ili ne? Sportska medicina, 7(1), 9-13.

Jovović, V. (1999). Tjelesni deformiteti adolescenata. Nikšić: Filozofski fakultet. Jovović, V. (2008). Korektivna gimnastika sa kineziterapijom. Nikšić: Filozofski fakultet - Nikšić

Jovović, V., \& Čanjak, R. (2012). Frequency of angular deformities of the knee joint of school children in relation to sex and ages. Glasnik Antropološkog društva Srbije, 47, 1-7.

Krsmanović, R., Mijanović, M., Krsmanović, C., i Krsmanović, B. (1995). Povezanost tjelesne visine i tjelesne težine sa parametrima pravilnog držanja tijela. Fizička kultura, 1(2), 90-5.

Mihajlović, I., \& Tončev, I. (2008). Establishment of the foot arch initial status in preschool children. Sport Science, 1(2), 44-9.

Mihajlović, I., Šolaja, M. i Petrović, M. (2010). Deformiteti stopala kod predškolske dece u odnosu na pol i uzrasnu dob. Glasnik antropološkog društva Srbije, 45, 475-81.

Mihajlović, I., Tončev, I., \& Hmjelovjec, I. (2008). Prevalence of flatfoot deformity in Boys depending on their age. Acta Kinesiologica, 2(2), 103-6.

Milošević, Z., i Obradović, B. (2008). Posturalni status dece novosadskih predškolskih ustanova uzrasta 7 godina. Glasnik antropološkog društva Srbije, 43, 301-9.

Pfeiffer, M., Koty, R., Ledl, T., Hauser, G., \& Sluga, M. (2006). Prevalence of flat foot in percolated children. Pediatrics, 118(2), 634-9.

Protić - Gava, B., i Krneta, Ž. (2010). Posturalni status dece mlađeg školskog uzrasta četiri okruga Vojvodine. Glasnik antropološkog društva Srbije, 45, 375-83.

Protić-Gava, B., i Šćepanović, T. (2012). Osnove kineziterapije i primenjena korektivna gimnastika Novi Sad: Faculty of sport and Physical education.

Radisavljević, D., Ulić, D., i Arunović, D. (1997). Senzitivni period razvojamotoričkih sposobnosti dece mlađeg školskog uzrasta. Fizička kultura, 60(2), 34-7.

Radisavljević, M. (2001). Korektivna gimnastika sa osnovama kineziterapije. Beograd: Fakultet fizičke kulture.

Sabo, E. (2006). Posturalni status dece predškolskog uzrasta na teritoriji opštine Sombor, Sremska Mitrovica i Bačka Palanka. Novi Sad: Viša škola za obrazovanje vaspitača.

Sabo, E (2003). Psihosomatski status dece predškolskog uzrasta pri upisu u os novnu školu. Neobjavljena doktorska disertacija. Fakultet fizičke kulture. Novi Sad.

Trajković, S., i Nikolić, M. (2008). Kanoničke relacije antropometrijskih mera i posturalnih poremećaja školske dece. Glasnik Antropološkog društva Srbije, 43, 379-85.

Ulić, D. (1997). Osnove kineziterapije. Novi Sad: SAI.

Ulić, D., Protić-Gava, B., i Madić, D. (1997). Promene posturalnog statusa gimnastičarki Srbije. U Zbornik sažetaka 5. naučno-stručni skup sameđunarodnim učešћem „Sport i zdravlje stanovnika", (194-196). Novi Sad: Fakultet fizičke kulture, Medicinski fakultet.

Videmšek, M., Klopčič, P., \& Karpljuk, D. (2006). The analysis of the arch of the foot in three-year-old children - a case of Ljubljana. Kinesiology, 38(1). 78-85.

Živković, D. (2009). Osnovi kineziologije sa elementima kliničke kineziologije. Niš: Fakultet sporta i fizičkog vaspitanja.

Živković, D., i Karaleić, S. (2006). Relacije morfoloških karakteristika i skoliotičnog lošeg držanja kod školske dece. In Proceedings of "Fis-communications 2006", (pp. 129-132). Niš: Faculty of Physical Education. 